\title{
ARRANGEMENT OF LAW BY STATE FINANCIAL AUTHORITY IN REALIZING NATIONAL BANKING INDUSTRY THAT'S HEALTHY AND DYNAMIC
}

\author{
H. Muammar Arafat Yusmad \\ Institut Agama Islam Negeri (IAIN) Palopo \\ E-Mail: muammar.arafat@yahoo.co.id
}

\begin{abstract}
The development of national banking nowadays are growing fast, competitive and integrative. One problem of Indonesian banking system related with practicing law arrangement which is a harmonization process toward legislations. The focus problems are: law arrangement in banking governance, the procedure of the law arrangement in achieving national bank industry which are healthy and dynamic. As intermediary institutions, bank should be in a healthy condition in order to gain public confidence and deserve to increase national economic growth. Based on the conceptual discussion, obtained arguments are: first, The law arrangement of national banking should be done coodinately between Otoritas Jasa Keuangan (OJK) and Bank Indonesia (BI); second, Procedure of law arrangement according to the function and authority of OJK and BI which the urgent subjects are to avoid conflict of norm, overlapping policies and limited validity of norm of the law case which happen and will be happen; and third, banking law arrangement include bank arrangement and supervision system, strengthening internal condition of the bank, empowering and protecting consumer with complaints mechanism and follow-up which are clear and measurable.
\end{abstract}

Keywords: law arrangement, banking, health and dynamic bank.

\begin{abstract}
Abstrak
Perkembangan perbankan nasional dewasa ini bergerak cepat, kompetitif dan integratif. Salah satu masalah dalam sistem perbankan nasional adalah terkait penataan hukum yang merupakan sebuah proses harmonisasi atas berbagai peraturan perundang-undangan. Fokus permasalahan yaitu: Penataan hukum dalam tata kelola perbankan, langkah-langkah penataan hukum dalam mewujudkan industri perbankan nasional yang sehat dan dinamis. Sebagai lembaga intermediasi, bank harus berada dalam kondisi sehat agar mendapatkan kepercayaan masyarakat dan mampu meningkatkan pertumbuhan ekonomi nasional. Berdasarkan pembahasan diperoleh argumen: pertama, Penataan hukum perbankan nasional harus dilakukan secara koordinatif antara Bank Indonesia (BI) dan Otoritas Jasa Keuangan (OJK); kedua, Penataan hukum berpedoman pada tugas dan kewenangan $\mathrm{BI}$ dan OJK yang urgensinya adalah untuk menghindari benturan antar norma hukum, ketidakjelasan norma dan keterbatasan jangkauan norma atas peristiwa hukum yang sedang dan akan terjadi; dan ketiga, Penataan hukum perbankan mencakup sistem pengaturan dan pengawasan bank, penguatan kondisi internal perbankan, dan, perlindungan konsumen dengan mekanisme pengaduan dan tindak lanjutnya yang jelas dan terukur.
\end{abstract}

Kata Kunci: penataan hukum, perbankan, bank sehat dan dinamis.

\section{Introduction}

The Constitution of Republic of Indonesia in 1945 (UUD 1945) mandates so that the national economy was held based on economic democracy with the principle of mutuality, the efficiency of justice, continuity, environmental insight, independence as well as maintaining the balance of economic progress and national unity. Development of national banking is fast-mo- ving, dynamic, competitive and integrated each other.

One of the problems in the system of national economy including in the banking sector is related law arrangement which is a process of harmonization of various laws and regulations. According to Jimly Asshiddiqie, during this time the issue was considered to not important considering the practice of organizing the economy since independence has been running just follow 
the flow logic of economic development that evolved on the basis of empirical experience on the field or the theories and stories of success in other countries which deserve to be role model. ${ }^{1}$

The principle of state responsibility in national law has got its form which implemented in some national legislation, both for "State Responsibility" as well as "State Liability", ${ }^{2}$ particularly in running the functions of banking intermediation. Before the enforceability of Act No. 21 year 2011 about the Otoritas Jasa Keuangan (OJK), Bank Indonesia (BI) has three obligations as a regulator of banking that is set up and maintain the fluency of payments systems, assign the monetary policy and keep the stability of rupiah, and regulate and supervise banking. With the formation of OJK, then ban-king supervisory and authority settings to OJK. The momentum tasks transition and authorities from $\mathrm{BI}$ to OJK should be accompanied by efforts to conduct the law arrangement so that between $\mathrm{BI}$ and OJK always work together in realizing a healthy and dynamic national banking.

Nevertheless, the presence of OJK in the national banking system doesn't escape from resistance in some quarters who precisely assume that OJK will rise new problem in the governance of national banking. The Sovereignty Defenders Team of The Nation's Economic even suing ACT of RI No. 21 year 2011 about OJK to Constitutional Court with questioning the arrangement and supervising authority (the bank) by OJK who they deem contrary to the Constitution. Another view which skeptics with OJK is, will happen "overlapping" or overlap the implementation of tasks and authorities towards bank arrangement which in turn will make $\mathrm{BI}$ and OJK become "doesn't get along" and run by its own way without clear coordination. This is where the need for a law arrangement by $\mathrm{BI}$ and OJK as state financial authority in banking field. Super-

Jimlly Asshiddiqie, “Konstitusi Ekonomi”, 2010, Jakarta: Kompas, page vii

2 Heru Prijanto, "Tanggung Jawab Negara dalam Doktrin Tindakan Negara", Journal of Konstitusi, Vol. I No. $1 \mathrm{Au}$ gust 2008, Malang: Law Faculty of Brawijaya University, page 76.

3 Muammar Arafat, "Aktualisasi Asas-asas Hukum Perbankan Guna Mencegah Tindak Pidana dalam Lingkup Per- vision toward banking performance should be further improved concern to the rampant cases in Indonesia today to take advantage of the administration system weakness and human resources at the bank. ${ }^{3}$

Focus of the problem from the explanation above are: first, the law arrangement form which done in national banking governance; second, procedure which has taken in conducting law arrangement toward national banking; and third, efforts to actualize national banking industry that's healthy and dynamic.

\section{Discussion}

The provisions of ACT No. 7 of Rl year 1992 about Banking as amended by ACT No. 10 of RI year 1998 describes several types of banking business with its primary function as a collecting agency and supplier of funds from the community. In general, banks are divided into two types: Public Bank: the banks that carry out business activities conventionally or based on the Sharia Principles in its work that providing services in payment traffic; and Bank Perkreditan Rakyat (BPR): namely banks that carry out the business activities conventionally or based on Sharia Principles which in its activities do not provide services in payment traffic.

The difference between two types of banks are discovered on service activities in payment process. In line with it, currently sharia economics (including sharia banking) as a "newcomer" in the banking industry also needs to be strengthen. It is caused by the Islamic tenets on the economy that the tenets are integral, inseparable, whether on wholly the Islamic tenets or on the reality of life. ${ }^{4}$ For example in the context of sharia banking, it is rarely to not assume that sharia banks were not much different from a conventional bank. These assumptions and statements are the indicator that the Moslem does

bankan Syariah", Jurnal Hukum Adil, Vol II No. 2, Auguts 2011. Jakarta: Law faculty of Yarsi University, page 219.

4 Yadi Janwari, "Tantangan dan Inisiasi dalam Implementasi Ekonomi Syariah di Indonesia". Jurnal Al-Ahkam", Vol. XII No. 2 July 2012, Jakarta: Law and Syariah Faculty of Syarif Hidayatullah Islamic State University, page 254. 
not understand very well about Islamic economy. ${ }^{5}$ Sharia banking is growing rapidly through product innovation market-based. The innovation must comply with the rules that had been established in Islamic law. ${ }^{6}$ The roles of DSN-MUI, DPS, BI and OJK are important to organize and super-vise the operational activities of sharia banking thus society do not "deceived" by sharia banking products which do not comply with sharia principles.

The acceleration of technological advance and the development of information are very fast so it must be balanced with the interpretation and the research of the Islam sharia doctrine based on al-Qur'an and Sunnah that must be actual and responsible. ${ }^{7}$ The Sharia (laws) Islamic tells about moral which is closely associated with human habits until the Islamic law could not be far from Islamic law surroundings, ${ }^{8}$ including Indonesia while the majority is Moslem. As a subsystem of sharia, sharia economics has the aim to make the happiness of each individuals and society are realized, both in the world and hereafter. ${ }^{9}$ Because the time continues to move, the period continues to change, and the people who are in the flow of time and the range of the era continues to change, then the attainment of former Islam expert must be continue to be examined in order to develop the scope and material enrichment that allows Islamic law to shelter and respond the development of period. ${ }^{10}$

\section{The Law Arrangement in Banking Field}

The inception of law products in the form of legislation cannot be separated from the re-

Ibid, page 256 .

Ibrahim Siregar, "Legal Aspect of "Gold Farming” Islamic Banking Product”, Jurnal Al-Ahkam, Vol. XIV No. 2 July 2014, Jakarta: Syariah and Law Faculty of UIN Syarif Hidayatullah, page 165 .

7 N. Oneng Nurul Badriyah dan Siti Rohmah, "Analisis Maslahah dalam Millenium Development Goals". Journal of Ijtihad, Vol. 13 No. 2 December 2013, Salatiga: Sekolah Tinggi Agama Islam Negeri Salatiga, page 142.

8 Mustaming, "Hukum Islam dalam Tata Hukum Pidana dan Perdata Nasional". Jurnal Al-Ahkam, Vol.2 No. 3 September 2010, Palopo: Sekolah Tinggi Agama Islam Negeri Palopo, page 20.

9 Anita Marwing, “Pengembangan Konsep Ekonomi Syariah dalam UURI No. 3 Tahun 2006 tentang Perubahan Atas UURI No. 7 Tahun 1989 tentang Peradilan Agama”, Jurnal sults of previous law products. The act was born as a positive response from the public, the legislature and the judiciary. ${ }^{11}$ Law arrangement is a "laws building" which consists of wide range legislation that is systematically arranged and structured. There are several agencies in conducting a laws arrangement of national banking field, which is integratively obliged to foster healthy and dynamic banking climate namely $\mathrm{BI}$ in terms of monetary policy and maintaining the stability of the rupiah currency and OJK in terms of banking supervision and arrangements.

Law arrangement which conducted must pay attention to the primacy of legislation principle enforceability which are: lex superiori derogate legi generale or higher degree regulations must take precedence over the rules. Therefore, in determining legislations related with national banking must to avoid conflicting arrangements between a regulation and other regulations including the avoid overlap of authority between the institutions concerned.

The law arrangement is made with attention to harmonization of legislation based on the Constitution. The founders of the Nations that make up the Constitution gives great concern about economics life arrangement on it. ${ }^{12} \mathrm{~A}$ previous attempt to create constructs need to be changed because it doesn't fit with the ius cogen (a basic rule which cannot be changed except by a new basic rules) such as by incorporating the
Muamalah, Vol. IV No. 1 April 2014, Palopo: Sekolah Tinggi Agama Islam Negeri Palopo, page 64.

10 Abad Badruzaman, "Dari Illah ke Maqashid: Formula Dinamisasi Hukum Islam di Era Kekinian Melalui Pengembangan Konsep Maqashid", Jurnal Ijtihad, Vol. 14 No. 1 June 2014, Salatiga: Sekolah Tinggi Agama Islam Negeri Salatiga, page 78 .

11 Hamzah Kamma, "Faktor Sosial dan Budaya Peraturan Perundang-undangan”, Jurnal Al-Ahkam, Vo. IV No. 2 August 2014. Palopo: Sekolah Tinggi Agama Islam Negeri Palopo, page 8.

12 Umar Juoro, "Implementasi Perubahan UUD 1945 dalam Pandangan Ekonomi”, Journal Konstitusi, Vol. 2 No. 2 September 2005, Jakarta: Mahkamah Konstitusi R.I., page 160 
principle of economic democracy on an amendment to the Constitution. ${ }^{13}$

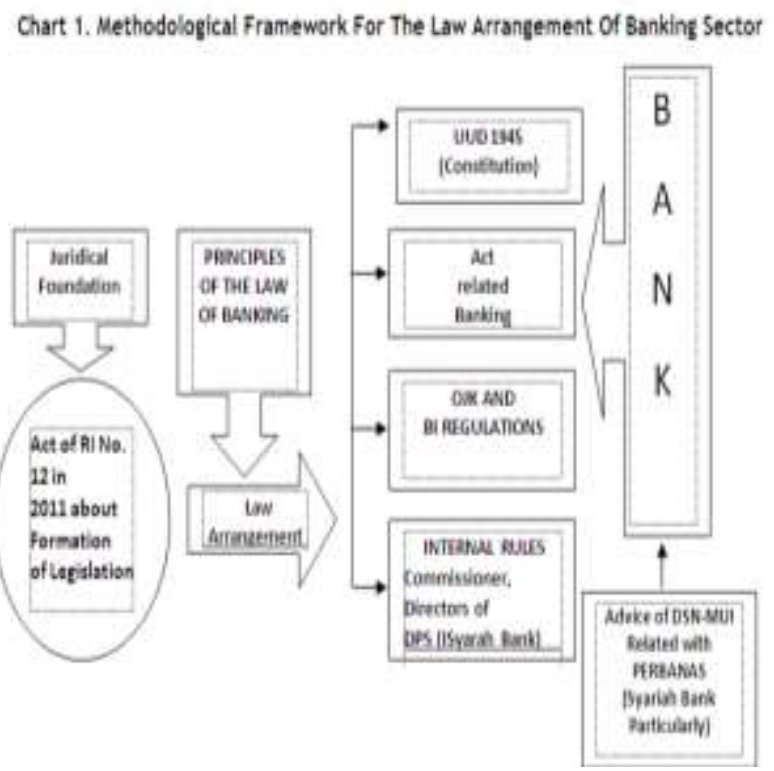

In fact, although the Government and the legislature has sought to do law arrangement integratively, but still found disharmony between legislations that potentially in occurance of authority conflict between agencies. For example, Act No. 21 of year 2011 about OJK can interfere $\mathrm{BI}$ performance in taking monetary policy which becomes $\mathrm{BI}$ authority because arrangement and supervision authority against banking including data and information access had been switched from BI to OJK. Scope of OJK authority is too large so that it goes beyond the authority of $\mathrm{BI}$ which posses monetary policy authorities in Indonesia. According to the provisions of article 69 of the ACT OJK, look how the multiplicity of authorities of the $\mathrm{BI}$ in act, Banking Act and Islamic Banking ACT which "amputated" by OJK Act. In the next will often happen differences of view about arrangement and supervision as well as licensing between OJK and BI.

\section{Procedures Which Taken in Conducting Law Arrangement}

National banking law arrangement must have a precise epistemology. OJK and BI may not be its own way of doing the law arrangement re-

13 Moh. Ridwan, "Analisis Politikolegal terhadap UUD 1945”, Jurnal Konstitusi, Vol. II No. 2 November 2009, Malang: Law Faculty of Brawijaya University, page 65. lated policies which issued on national banking. OJK and BI should be compact in its duties according to law. OJK authority in the field of setting and monitoring requires OJK minding related microprudential policies which integrative in national banking industry. Whereas $\mathrm{BI}$ is authorized to issued a microprudential policy that is monetary policy to keep inflation, interest rates and the stability of rupiah.

The national banking industry nowadays grown considerably which marked by varied and innovative banking products. The OJK's key to success is by always synergize with $\mathrm{BI}$ and all other stakeholders such as Lembaga Penjamin Simpanan (LPS) and Pusat Pelaporan dan Analisis Transaksi Keuangan (PPATK). The law arrangement by OJK and $\mathrm{BI}$ after task arrangement and supervision task switch should be conducted in a comprehensive, integrative and continue. The urgency of the juridical aspects arrangement is to avoid conflict between law norms (conflict of norm), lack of norms and limitations of these top law norms range that are and will be.

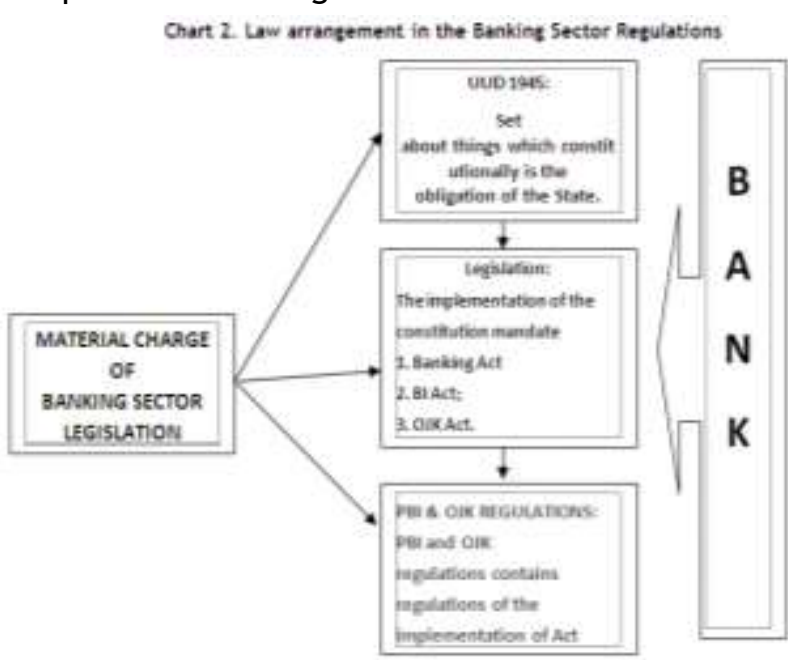

Actual zinging National Banking Industry That's Healthy and Dynamic

Realizing democratic national economic system and social justice awareness is not just a brand, but actually meant a process of becoming Indonesia. ${ }^{14} \mathrm{OJK}$ and $\mathrm{BI}$ in an attempt to realize banking industry which are healthy and dynamic

14 Rahmat Syafaat, "Peranan Hukum Progresif dalam Transformasi Sistem Ekonomi Nasional yang Berkeadilan Sosial”, Jurnal Konstitusi, Vol. II No. 2 November 2009, Malang: Law Faculty of Brawijaya University, page 80. 
issued various regulations in accordance with their authority to regulate activities in the banking sector.

OJK and $\mathrm{BI}$ is authorized to establish a banking law that substance into a mandate of the Constitution and as an implementation rule of legislation in the banking sector. Law arrangement by OJK and BI are: first, OJK Regulation No.1/POJK.7/2013 about Protection of Consumers of Financial Services Sectors. OJK has set up a complaints mechanism and service system for consumers whom harmed by businessmen in the banking sector and facilitate bank customer compliance. For example, the debtor had paid off the installment but the collateral is still being detained by the bank. If the problem is between the customer and the bank has not completed, then the customer can report it on customer service. Second, PBI No. 3/PBI/10/2001 about the implementation of know your customer principles. This principle is applied by the bank to find out the customer identity, to monitor the customer's transaction activity and to report a suspicious transaction at the Center of Financial Transaction Reporting and Analysis (PPATK). When a prospective customer does not qualify with know your customer principle, the bank is prohibited to do business relations with the prospective customer. $\mathrm{PBI}$ about the implementation of know your customer principles, should be revised immediately because it is not in accordance with the dynamics of banking transaction activity development that is increasingly more complex. PBI should synergize with Law No. 8 of 2010 about Prevention and Eradication of Money Laundering Criminal (TPPU). TPPU has been modified several times considering the extensive criminal that become suspicious transactions. PBI, about know your customer principle in the enclosure, should enclose the types of suspicious transaction and not only enclose the transaction system but also about withdrawals, money exchange and transfer. Third, PBI No. 6/ 10/2004 about The Assessment of Public Bank Health Level. The health level of the bank is a qualitative assessment against the factors that affect bank operational which is include: capi- tal, asset quality, management, earning ratios, liquidity, market risk sensitivity. Fourth, PBI No. 9/1/PBI/2007 about the Assessment System of Commercial Banks Health Level based on Sharia Principles. PBI is essentially same with PBI No.6/25/PBI/2004, regarding health level assessment system of public bank. It is on the operational system of banking that votes that's commercial banks based on sharia principles. Fifth, PBI No. 3/2/PBI/2013 about Status Assignment and Follow Up Surveillance of Conventional Commercial Banks. BI regulation is made at the time of $\mathrm{BI}$ service in its overseeing bank coming to an end. Counted since $31^{\text {st }}$ December of 2013, the banking supervision will switch to OJK. Principal problems in the governance of national banking intermediation is as bad debts which in turn will give rise to a deficit on the balance of the transaction is running. Credit given by the banks definitely contains risks so that in practice the banks should look at the mechanism of credit granting in the process of credit/ financing. Still a high number of bad debts in Indonesia is caused by several factors such as the lack of prudence bank principle implementation in the process of organization, poor credit management organization, the prudence of approval credit granting that tend to lead to approach personal relationships and not a professional so the element of deliberate action in making policy about gran-ting the credit (error omission), and supervision of a weak credit execution.

In an attempt to realize the national banking industry that healthy and dynamic, a structured and comprehensive laws that include system settings and monitoring of effective bank with a complete infrastructure arrangement is needed, a national banking structure which healthy and dynamic that able to exercise its function as intermediary institutions, strengthen the internal conditions of national banking through good corporate governance and empowerment as well as banking services with consumer protection complaint mechanisms and follow ups which are clear and measurable. 


\section{Closing}

After issue which became the topic of this research are outlined and analyzed, then law arguments built: first, law arrangement of national banking should be done coordinately between OJK and BI. The OJK's success key is by always synergize with $\mathrm{BI}$ and all other stakeholders such as Lembaga Penjaminan Simpanan (LPS) and Pusat Pelaporan dan Analisis Transaksi Keuangan (PPATK). The law arrangement by OJK and $\mathrm{BI}$ after bank arrangement and supervision task switch should be conducted in a comprehensive, integrative and continue. Second, Procedure of law arrangement according to the function and authority of OJK and BI which the urgent subjects are to avoid conflict of norm, overlapping policies and limited validity of norm of the law case which happen and will be happen. Third, in order to realize the national banking as an industry is healthy and dynamic, the Setup needed a structured and comprehensive law by OJK and BI system that includes setting and supervision of banks, national banking structure, strengthening of internal national banking condition through good corporate governance, and, banking services consumer empowerment and protection with the complaint mechanisms and follow ups which clear and measurable.

\section{References}

Arafat, Muammar. "Aktualisasi Asas-asas Hukum Perbankan Guna Mencegah Tindak Pidana dalam Lingkup Perbankan Syariah". Journal of Hukum Adil, Volume II No. 2 August 2011. Jakarta: Law Faculty of Yarsi University.

Asshiddiqie, Jimly. "Konstitusi Ekonomi" Kompas Jakarta. 2010.

Badruzaman, Abad. "Dari Illah ke Maqasid: Formula Dinamisasi Hukum Islam di Era Kekinian Melalui Pengembangan Konsep Maqasid". Journal of ljtihad, Vol.14 No. 1 June 2014. Salatiga: Sekolah Tinggi Agama Islam Negeri (STAIN) Salatiga.

Janwari, Yadi. "Tantangan dan Inisiasi dalam Implementasi Ekonomi Syariah di Indone- sia”. Jurnal Al-Ahkam, Vol. XII No. 2 July 2012. Jakarta: Sharia and Law Faculty of Syarif Hidayatullah Islamic State University;

Juoro, Umar. "Implementasi Perubahan UUD 1945 dalam Pandangan Ekonomi". Jur-nal Konstitusi Vol. II No. 2 September 2005. Jakarta: Mahkamah Kon-stitusi Republik Indonesia;

Kamma, Hamzah. "Faktor Sosial Budaya dan Aturan Perundang-undangan di Indonesia". Jurnal Al-Ahkam, Vol. IV No. 2 August 2014. Palopo: Sekolah Tinggi Agama Islam Negeri Palopo;

Marwing, Anita. “Pengembangan Konsep Ekonomi Syariah dalam UURI No. 3 Tahun 2006 tentang Perubahan Atas UURI No. 7 Tahun 1989 tentang Peradilan Agama". Jurnal Muamalah. Vol. IV No. 1 April 2014. Palopo: Sekolah Tinggi Agama Islam Negeri Palopo;

Mustaming. "Hukum Islam dalam Tata Hukum Pidana dan Perdata Nasional". Journal of Al-Ahkam, Vol. II No. 3 September 2010. Palopo: Sekolah Tinggi Agama Islam Negeri Palopo;

Oneng Nurul Badriah N, et al. "Analisis Maslahah dalam Millenium Development GoaIs". Jurnal Ijtihad, Vol. 13 No. 2 December 2013. Salatiga: Sekolah Tinggi Agama Islam Negeri Salatiga.

Prijanto, Heru. "Tanggung Jawab Negara dalam Doktrin Tindakan Negara". Jurnal Konstitusi, Vol. 1 No. 1 August 2008. Malang: Law Faculty of Brawijaya University;

Ridwan, Mohammad. "Analisis Politikolaw terhadap UUD 1945". Jurnal Konstitusi, Vol. 2 No. 2 November 2009. Malang: Law Faculty of Brawijaya University;

Siregar, Ibrahim. "Law Aspect of "Gold Farming" Islamic Banking Product". Jurnal of AlAhkam, Vol. XIV No. 2 July 2014, Jakarta: Sharia and Law Faculty of UIN Syarif Hidayatullah Islamic State University;

Syafaat, Rahmat. "Peranan Hukum Progresif dalam Transformasi Sistem Ekonomi Nasional yang Berkeadilan Sosial". Journal of Konstitusi, Vol. II No. 2 November 2009 Edition. Malang: Law Faculty of Brawijaya University. 